\title{
REASON, CONTRACT, AND LAW IN LABOR RELATIONS $\dagger$
}

\author{
Harry Shulman *
}

T OLMES did not have much occasion as judge to deal with 1 the organization of labor and collective bargaining. But when he did, he stated what he called "the less popular view of the law." 1 To Holmes, our system of free enterprise and democratic government required the state, subject to the limitations of public order, to permit workers to organize and to extend their organization for the purpose of strengthening their bargaining position in the struggle for a better share in return for their services. Their shares were to be determined by the parties to the struggle, not by the state; and the state should not interfere so as to make the struggle unequal. Thus, when dealing with picketing to enforce a wage demand, he said in 1896 :

One of the eternal conflicts out of which life is made up is that between the effort of every man to get the most he can for his services, and that of society, disguised under the name of capital, to get his services for the least possible return. Combination on the one side is patent and powerful. Combination on the other is the necessary and desirable counterpart, if the battle is to be carried on in a fair and equal way. ${ }^{2}$

And when dealing with threatened strikes and boycotts to compel employment of members of defendants' union only, he said:

[The defendants'] purpose was not directly concerned with wages. It was one degree more remote. The immediate object and motive was to strengthen the defendants' society as a preliminary and means to enable it to make a better fight on questions of wages or other matters of clashing interests. I differ from my brethren in thinking that the

$\dagger$ This paper was delivered as the Oliver Wendell Holmes Lecture at Harvard Law School on February 9, I955, a little over a month before Dean Shulman's death.

* Late Dean and Sterling Professor of Law, Yale Law School. A.B., Brown, I923; LL.B., Harvard, I926, S.J.D., I927.

${ }^{1}$ Vegelahn v. Guntner, I67 Mass. 92, I04, 44 N.E. Io77, I079 (I896) (dissenting opinion).

${ }^{2}$ Id. at 108, 44 N.E. at 108r. 
threats were as lawful for this preliminary purpose as for the final one to which strengthening the union was a means. ${ }^{3}$

Perhaps the social and economic history of the United States would have been significantly different if in these cases Holmes were stating the prevalent view rather than speaking in dissent. His dissenting view did prevail. But it was not until the National Labor Relations Act ${ }^{4}$ became effective that the workers' freedom of association was safeguarded by the imposition of a correlative duty on employers to refrain from interfering with or restraining the workers' choice. And the workers' right to collective bargaining was then enforced by an affirmative duty on the employer to recognize and bargain with the representative designated by them, on wages, hours, and other conditions of employment. ${ }^{5}$

This bare legal framework is hardly an encroachment on the premise that wages and other conditions of employment be left to autonomous determination by employers and labor. On the contrary, it merely establishes the conditions necessary for the exercise of that autonomy. But, as is perhaps inevitable, the statement of a legal duty to bargain collectively on wages and conditions of employment leads to demand for legal definition of the scope of the duty. What matters are included in the phrase "conditions of employment"? And is a party's legal duty to bargain satisfied when it persistently demands unilateral discretion on one or more items and refuses to concede to the other side any voice in their determination?

The questions of what the parties should bargain about and what they should leave to unilateral rather than joint determination could, of course, be left to the parties themselves. They could decide whether to bargain about pensions or the number of shifts in the same way that they decide whether to have a wage increase or how much of an increase. That would involve the possibility of a cessation of production because of stalemate on these issues; but such an interruption is an integral part of collective bargaining. The results might then differ from one enterprise to another; one might bargain about pensions, the other might not; one might place a matter under unilateral control,

${ }^{3}$ Plant v. Woods, I76 Mass. 492, 505, 57 N.E. Iorr, IoI6 (Ig00) (dissenting opinion).

449 STAT. 449 (I935), as amended, 29 U.S.C. $\S \S 55 I-68$ (I952).

$5 \S 8$ (a) (5), 9(a), 49 STAT. 453 (I935), as amended, 29 U.S.C. $\S \S ~ I 58(a)(5)$, I59(a) (r952). 
the other might make it a matter of joint determination. But such differences would be quite in accord with the postulate of autonomous determination through collective bargaining.

In an enterprise in which collective bargaining is just making its appearance, if the law in its administration surveys the course of the apparent bargaining and determines that it is apparent rather than real, because of the scope of the demands for unilateral discretion, the law may well be merely enforcing the duty to bargain rather than shaping the content of the bargain. But in an enterprise in which collective bargaining is an accepted and going institution, if the law commands that some particular item must be made the subject of bargaining and may not be the object of a firm demand for unilateral control, then to that extent the law interferes with the parties' autonomy and shapes the content of their bargain. Such decisions tend to become not only definitions of the legal duty to bargain but also statements of the maximum that the parties may in practice seek from one another.

The law intervenes in another way. The parties' bargaining normally results in a collective labor agreement for a stated term or for an indefinite period. The agreement is made on the understanding and with the expectation that both parties will respect it as a commitment binding upon them. In the business world such commitments are called contracts. And the collective labor agreement itself comes to be called the contract even by the workers as, for example, in the slogan "no contract, no work." Does it not naturally follow, then, that the law which provides remedies for breaches of contract generally should also provide remedies for breaches of collective labor agreements? If the parties are entrusted by law with the responsibility of determining conditions of employment, should they not be held to their responsibility and their agreements be given the sanction of legal enforcement? This is the line of reasoning which apparently persuaded the Congress to invest the federal courts with jurisdiction over actions for breach of contract between employers and labor organizations. ${ }^{6}$

Again, if the collective agreement provides for resort to voluntary arbitration, it is argued that the law should enforce the agreement; and provision is made for suits to enjoin or compel the arbitration or to enjoin or enforce the resulting awards. This

${ }^{B}$ Labor Management Relations Act, § 30r(a), 6I STAT. I56 (I947); 29 U.S.C. $\S 185$ (a) (I952). 
limited intervention by the law, it is argued, is not an impairment of the freedom of contract but rather a means of making it effective.

In my judgment, these are unwise limitations on the parties' autonomy. For me this conclusion follows from the analysis which I propose to make of the rule of law and reason which the parties' contract - the collective agreement - establishes. But the analysis has validity, whether or not you draw the same conclusion.

While what I shall say may have wider application, my archetype is a large industrial enterprise employing many thousands of organized workers in one or more plants. It is necessary to bear in mind that such an enterprise involves not only large groups of organized workers but also an employer who acts through many hundreds or thousands of representatives at various levels of authority from the job foreman through the superintendents and managers to the vice-presidents and president and board of directors. While the organization on the employer side is more monolithic than on the worker side, the fact that many people exercise its authority in various ways is of great practical significance.

Collective bargaining today is not concerned merely with the return for the employees' services that Holmes talked about. ${ }^{7}$ That is, of course, one important concern. On occasion all attention seems to be focused on it. But wages are negotiated only periodically, once in six months, or twelve months, or perhaps even at longer intervals. Even when wages appear to be the chief or only matter in controversy, there is a great deal more involved - more which is not only of at least equal importance but which also affects the wage negotiations.

Collective bargaining is today, as Brandeis pointed out, the means of establishing industrial democracy as the essential condition of political democracy, the means of providing for the workers' lives in industry the sense of worth, of freedom, and of participation that democratic government promises them as citizens. ${ }^{8}$ The modern industrial worker is not engaged to produce a specific result and left to himself for the performance. $\mathrm{He}$ is hired to

\footnotetext{
${ }^{7}$ See p. 999 supra.

${ }^{8}$ See Hearings Before the U.S. Commission on Industrial Relations, S. Doc. No. 4I5, 64th Cong., Ist Sess. 99I-IOII, 7657-8I (IgI4-I5), reprinted in part in Branders, The CuRse of Bigness 70-95 (Fraenkel ed. I934).
} 
work under continuous and detailed direction and supervision, in close association with hundreds or thousands of fellow workers, each of whom performs a very minute portion of the work that ultimately results in a finished product. The enterprise requires the continuous co-ordination of the work of this multitude of employees; and this poses numerous daily problems whether or not the employees are organized. So elementary a matter as leaving the job for a few minutes "to service the body," as they say in the shop, poses a serious problem which must be carefully analyzed and provided for, otherwise one might find the work of a hundred men held up every time one of them had to leave. Every day a number of employees may be absent or report late. Daily or almost daily some employees have to be laid off for a short period or indefinitely; some employees must be hired; changes must be made in job assignments, either by way of promotion or demotion or otherwise. And daily there are thousands of occasions for friction between employee and supervisor which may erupt in disciplinary action against the employee or a stoppage of work.

These and a host of similar problems are inherent in the necessity of co-ordinating the work of thousands of persons into an efficient operation. Even where there is no union, the employer needs statements of policy to guide the hundreds of persons through whom he must act, though he may be ready to invest them with large powers of discretion. Addition of the union alters the situation in at least two ways: First, the employees, through the union, must participate in the determinations. Second, the acceptance of unions and collective bargaining has increased the employee's confidence and his sense of dignity and importance; where previously there may have been submission, albeit resentful, there is now self-assertion.

One might conceive of the parties engaging in bargaining and joint determination, without an agreement, by considering each case as it arises and disposing of it by ad hoc decision. But this is, of course, a wholly impractical method, particularly for a large enterprise. So the parties seek to negotiate an agreement to provide the standards to govern their future action.

In this endeavor they face problems not unlike those encountered wherever attempt is made to legislate for the future in highly complex affairs. The parties seek to foresee the multitude of variant situations that might arise, the possible types of action that might then be available, the practicalities of each and their 
anticipated advantages or disadvantages. Choice between the suggested possibilities is rendered more difficult by the very process of bargaining and the expected subsequent administration of the bargain. The negotiations are necessarily conducted by representatives removed in variant degrees from direct confrontation with the anticipated situations. They act on the basis partly of their own experience and partly of the more or less incomplete or clashing advice of constituents - the resolutions of councils, subcouncils, unit and departmental meetings in the case of the union, and the suggestions from individuals at the various levels of management in the case of the employer. While each area of problems - vacations, overtime, promotions, layoffs, and the like - must be separately and carefully considered, each is nevertheless but a small part of the total negotiation. The pressure for trade or compromise is ever present.

No matter how much time is allowed for the negotiation, there is never time enough to think every issue through in all its possible applications, and never ingenuity enough to anticipate all that does later show up. Since the parties earnestly strive to complete an agreement, there is almost irresistible pressure to find a verbal formula which is acceptable, even though its meaning to the two sides may in fact differ. The urge to make sure of real consensus or to clarify a felt ambiguity in the language tentatively accepted is at times repressed, lest the effort result in disagreement or in subsequent enforced consent to a clearer provision which is, however, less favorable to the party with the urge. With agreement reached as to known recurring situations, questions as to application to more difficult cases may be tiredly brushed aside on the theory that those cases will never - or hardly ever - arise.

Then there is never, of course, enough time to do an impeccable job of draftsmanship after substantive agreement is reached apart from the hazard that such an effort might uncover troublesome disagreement. Though the subject matter is complex and the provisions intricate, the language must nevertheless be directed to laymen whose occupation is not interpretation - the workers in the plant, the foremen, the clerks in the payroll office. For it is they whose actions must be guided by the agreement; and indeed, in the case of the union, the membership is asked to ratify or reject what is prior to its action only a proposed agreement. While the interpretations or explanations made at the member- 
ship meetings can hardly bind the employer, it is nevertheless important that the agreement be not such as to become a promise to the ear but a disappointment to the hope of the membership.

To be sure, the parties are seeking to bind one another and to define "rights" and "obligations" for the future. But it is also true that, with respect to nonwage matters particularly, the parties are dealing with hypothetical situations that may or may not arise. Both sides are interested in the welfare of the enterprise. Neither would unashamedly seek contractual commitments that would destroy the other. Each has conflicts of interests in its own ranks. Both might be content to leave the future to discretion, if they had full confidence in that discretion and in its full acceptance when exercised. And even when the negotiating representatives have full confidence in each other as individuals, they recognize that it will be many others, not they, who will play major roles in the administration of the agreement. So they seek to provide a rule of law which will eliminate or reduce the areas of discretion. The agreement then becomes a compilation of diverse provisions: some provide objective criteria almost automatically applicable; some provide more or less specific standards which require reason and judgment in their application; and some do little more than leave problems to future consideration with an expression of hope and good faith.

Consider, for example, the role of seniority. Specifically, the parties seek to provide for the selection of employees for promotion, or for layoff should it become necessary to reduce force; and seniority is urged as the touchstone for the selection. Seniority here means not chronological age, or length of service in the particular industry or in industry generally. It means rather length of service for the particular employer in the particular seniority unit of that employer. When the union insists that seniority shall govern promotions to better jobs, it is not because the union does not admit the desirability of recognizing superior ability and encouraging ambition and greater effort; nor is it because the union is unaware that the progress of some of its worthy members will be retarded by a strict seniority rule. Again, when the union demands that layoffs shall be made by strict order of seniority, it is not because of unawareness of the other factors that might appeal, for example, to the social worker. The union is well aware that layoff by seniority may in some instances cause greater hardship than would be the case if other factors 
were considered. It knows that in a particular case, the senior employee in the given seniority unit may be a relatively young man with no dependents and with considerable mobility that would enable him to find some work elsewhere; while the junior employee may be a relatively old man with a lot of service in the industry, many dependents, and little chance of finding work elsewhere. To be sure, there is the general opinion that long service deserves of itself some reward and preference. But the seniority rules of which I speak apply at all periods of service - to the men with one or two years of service or less, as well as to those with ten, fifteen, or more. And a difference of a day or a week is made determinative in the selection. Moreover, seniority is commonly not a factor in determining the employee's pay for his work. He receives the rate for the job whether he has been on it a year or ten years.

I suggest that the insistence on seniority, like the insistence on single rates of pay for specific jobs, is based in large part on the desire or need for an objective rule which eliminates judgment and discretion in particular cases. And that is not merely because the union is unwilling to lodge discretion in the employer. I daresay that if the employer were willing to grant to the union complete control over promotions and layoffs, the union would adopt the seniority standards in order to curb its own discretion. For the exercise of discretion in these cases is a very difficult task and its fairness or soundness is always subject to attack - more or less violent. When it is recognized that the purpose is not merely that of rewarding seniority, but is also to provide a fair, objective measure which would curtail arbitrary power or discretion, the range of possible adjustments is significantly altered.

Now contrast the different matter of discipline. Here, too, the parties recognize that occasion for disciplinary action will arise and that disciplinary action is something of a necessity. But whereas a reduction of force requires a selection among employees which necessarily means preference of some employees over others, disciplinary action poses no problem of preference. The union can generally seek to protect each employee threatened with disciplinary action without subordinating an interest of other employees. Here that protection requires the exercise of fair and humane judgment and discretion which takes into account all mitigating factors that can be mustered for the particular em- 
ployee. The problem, at least for the union, is not that of eliminating the pains of discretion, but rather that of confining the employer's power and providing maximum opportunity for the union to challenge the soundness of his exercise of discretion, while for the employer the problem is that of reducing this vulnerability of the disciplinary action taken by him. So most collective agreements do not go much beyond recognizing the employer's power to discipline or discharge and providing that the action shall be for cause, or good cause, and shall be subject to challenge by the employee and the union, subject to a few limitations or exceptions.

The parties recognize, when they make their collective agreement, that they may not have anticipated everything and that, in any event, there will be many differences of opinion as to the proper application of its standards. Accordingly the agreement establishes a grievance procedure or machinery for the adjustment of complaints or disputes during its term. The autonomous rule of law thus established contemplates that the disputes will be adjusted by the application of reason guided by the light of the contract, rather than by force or power.

While the details of the grievance procedure differ from one enterprise to another, its essence is a hierarchy of joint conferences between designated representatives of the employer and the union. But joint conferences even at the highest levels of authority may not, and frequently do not, result in agreement. In the absence of provision for resolution of stalemate, the parties are left to their own devices. Since grievances are almost always complaints against action taken or refused by the employer, a stalemate means that the employer's view prevails. Of course, in the absence of some restraint by contract or otherwise, the union is free to strike in order to reverse the employer's choice. But the union can hardly afford an all out strike every time it feels that a grievance has been unjustly denied. The consequence is either that unadjusted grievances are accumulated until there is an explosion, or that groups of workers, less than the entirety, resort to job action, small stoppages, slowdowns, or careless workmanship to force adjustment of their grievances.

The method employed by almost all industry today for the resolution of stalemates in the adjustment of grievances under the private rule of law established by the collective agreement is private arbitration by a neutral person. The largest enterprises 
provide for a standing umpire or arbitrator to serve for a stated period of time or so long as he continues to be satisfactory to both sides. The great majority of agreements provide for separate appointment of an arbitrator in each case. And the appointments in any case are made by the parties or by a method agreed upon by them. The wide acceptance of arbitration as a terminal step in the grievance procedure - as contrasted with its relatively limited use in the making of the contract in the first place - is explained generally on the grounds, first, that grievances involve interests of lesser importance than those in contract negotiation and, second, that the discretion of the arbitrator is confined by the agreement under which the grievances arise. Both statements require qualification. As umpire under one collective agreement, I have arbitrated cases ranging all the way from the claim of a single employee for fifteen minutes' pay to that of more than sixty thousand employees for a paid lunch period the direct cost of which was between seven and eight million dollars a year. And the restraining bonds of the collective agreement are found on occasion to be elastic indeed.

The parties do not generally restrict their own joint powers in the grievance procedure. But it is customary for the collective agreement to limit the arbitrator's jurisdiction with apparent strictness. Apart from the specific exclusion of certain subjects, as, for example, rates for new jobs or production standards, he is commonly confined to the resolution of grievances or disputes as to "the interpretation or application of the agreement," or of claims of "violation of the agreement." And quite frequently he is further enjoined not to "add to, subtract from, or modify any of the terms of the agreement." In the agreement with which I am most familiar he is admonished also that he has "no power to substitute his discretion for the Company's discretion in cases where the Company is given discretion" by the agreement, and no power "to provide agreement for the parties in those cases where they have in their contract agreed that further negotiations shall or may provide for certain contingencies." 9

Doubtless these are wise, perhaps even necessary, safeguards - at least before the parties develop sufficient confidence in their private rule of law to enable them to relax the restriction. And an arbitrator worthy of appointment in the first place must

${ }^{8}$ Agreement Between Ford Motor Co. and United Automobile Workers, CIO, art. III, §2I (I949, r950). 
conscientiously respect the limits imposed on his jurisdiction, for otherwise he would not only betray his trust, but also undermine his own future usefulness and endanger the very system of selfgovernment in which he works. But these are hardly provisions which would be inserted in the agreement to control the courts in an action on the contract. The judge, too, must decide only "according to law." Unlike the case of the arbitrator, however, the judge's authority and the law which he must interpret and apply do not derive entirely from the agreement of the litigants before him.

Let me consider some of the difficulties and limitations of the arbitrator's function. Suppose the collective agreement is completely silent on a matter in dispute. Suppose, for example, that the agreement is silent on the question whether acceptance of overtime work is mandatory or optional with the employee. This very issue was reported as the cause of the recent extensive and vexing strikes on the English docks. ${ }^{10}$ It is an issue which a number of arbitrators have had to decide under collective agreements. Now it is easy enough to say that the matter is not covered by the agreement. But what follows? May the employer, therefore, require the employees to accept the overtime assignments on pain of disciplinary penalties, such as layoff or discharge, or may the employees properly refuse the assignments? Answer would be aided, of course, if there were a common presupposition as to the effect of the collective agreement. In constitutional law terms, but without pushing the metaphor far, is it a grant of limited powers or is it a set of restrictions on otherwise unlimited powers? If it is the former and the employer is not given the power to command overtime work, then his attempt to discipline employees for failure to accept would be a violation of the contract; if it is the latter, then, since by hypothesis the agreement contains no relevant restriction, the employer would have the "reserved power" to enforce the command.

Partly for the purpose of meeting this difficulty many agreements now include what is generally called a "management prerogative" clause, sometimes more accurately and tactfully called a "management responsibility" or "management functions" clause. This normally lists certain matters as "the sole right" of management or for "sole determination" by management, sub-

${ }^{10}$ See N.Y. Times, Oct. I7, I954, p. 22, col. I. 
ject, however, to such restriction as may be provided in the agreement. The inclusion of the management provision in some agreements may raise a question as to the significance of its exclusion in others; and it focuses attention on the precise language of the provision with possible reference to the maxim inclusio unius est exclusio alterius. Apart from its specification of items as to which there is normally no question, such as the products to be manufactured, the provision is normally couched in broad phrases like "the right to manage the business" or to "direct the working forces." One may wonder about the chances of the adoption of an agreement, in some enterprises at least, if it states in unmistakable language that the employer shall have the right to do anything at all with respect to the work of the employees except as he is expressly limited by the agreement.

Courts, if confronted with this problem, would doubtless declare a general principle, whether or not it squared with the conception of the parties in the particular case. But the power of the arbitrator to do so is at least questionable. The obvious alternative is for the arbitrator to refrain from affirmative decision and to remand the dispute to the parties on the ground that it is outside of his jurisdiction. But would not that be in effect a decision supporting the employer's freedom of action? If the validity of the employer's order requiring the overtime work is beyond the arbitrator's jurisdiction, he would seem to have no power to restrain the disciplinary action taken by the employer to enforce the order. On the other hand, if he does restrain the disciplinary action, is he not in effect denying validity to the employer's order? Again, the denial of jurisdiction presumably leaves the dispute for resolution by the parties. But whether the union may properly resort to economic pressure in the effort at resolution may depend upon the construction of the "no strike" provision of the agreement. The obligation not to strike may or may not be coextensive with the arbitrator's jurisdiction.

The question of fundamental presuppositions arises in another way. The parties rarely start with an enterprise from scratch; generally they negotiate an agreement for a going enterprise which has been in operation for some time and which has developed practices or precedents of varying degrees of consistency and force. What is the significance of the claimed "prior practice"?

For example, in the overtime case we have been considering, 
suppose that evidence is tendered that the employer never sought to compel acceptance of overtime assignments, or that the employees never refused such assignments without good excuse. Or suppose that, though the agreement is silent on the matters, the employer had been giving the employees a rest period of ten minutes in each half of the shift, or a lunch period on the employer's time, or a five minute wash-up period before lunch or at the end of the shift, or a money bonus at Christmas. Or, to vary the nature of the example, suppose the claim is that it had been customary for the employer to assign a rigger to assist pipefitters when they were required to lift pipe of four inches or more in diameter, or to assign an employee to hold the pieces which a welder had to weld. Now suppose that, during the term of the agreement, the employer changes these claimed practices over the union's strenuous objections, which are then carried through the grievance procedure to the umpire. In these cases it is the union which relies on the prior practice. But frequently the position is reversed. For example, an employer directs a punch press operator to paint his press when he has no punching to do; or he asks a crib attendant to paint the walls of his crib. In either case, the employee refuses on the ground that painting is not work in his classification, but rather in that of a painter. And the employer points to a claimed prior practice in accord with his direction.

Again the fundamental question may be asked: Is the agreement an exclusive statement of rights and privileges or does it subsume continuation of existing conditions? And again it may be ventured that courts, if confronted with the question, would probably give a general answer for all cases. For the arbitrator, particularly if his jurisdiction is limited to "interpretation" with a prohibition against "adding to, subtracting from or modifying" the terms of the agreement, a general answer is not so clear.

Some have urged that established practices, at least if they were in existence at the time of the negotiation of the agreement and were not considered in any way during the negotiations, are binding upon the parties and must be continued for the duration of the agreement. This, it is said, is implied in the agreement itself - or in the "logic" of the agreement or in the collective bargaining relationship. Lawyers are familiar with "implied" terms. We used to differentiate between implications "in fact" and implications "in law." Now scholars say the differentiation 
is not quite valid and the implication in any event is based on morality, common understanding, social policy, and legal duty expressed in tort or quasi-contract. The common understanding of the litigants in the particular action is only one factor in the implication - and not the most important. But the judges' authority for imposing the implication is not the party's will; it is the superior authority of the law, which transcends the party's will.

The arbitrator of whom we are talking does not have such superior authority to impose implied conditions. The implications which he may find are only those which may reasonably be inferred from some term of the agreement. Is there an implication "in fact" in the collective agreement that existing practices must be continued until changed by mutual consent? It may be said parenthetically that the legal duty to bargain is not quite relevant because, apart from the question whether the arbitrator may enforce that duty, the issue is whether the practice may be changed without mutual consent when bargaining has failed to achieve consent.

It is more than doubtful that there is any general understanding among employers and unions as to the viability of existing practices during the term of a collective agreement. There may be some agreements which are negotiated upon a real or tacit assumption of continuance of existing practices except as modified by the agreement. There are certainly some agreements which specifically provide for the continuance of existing practices with variant limitations. But I venture to guess that in many enterprises the execution of a collective agreement would be blocked if it were insisted that it contain a broad provision that "all existing practices, except as modified by this agreement, shall be continued for the life thereof unless changed by mutual consent." And I suppose that execution would also be blocked if the converse provision were demanded, namely, that "the employer shall be free to change any existing practice except as he is restricted by the terms of this agreement." The reasons for the block would be, of course, the great uncertainty as to the nature and extent of the commitment, and the relentless search for costsaving changes. The larger the enterprise, the more varied its operations, the more dependent it is on technological change, and the keener the competition the greater this uncertainty and search. The agreement between Bethlehem Steel and the United Steel- 
workers steers a middle course. It provides that if management changes any local practice or custom, an affected employee may file a grievance and in "the disposition of the grievance the burden shall be on Management to justify its action." 11 The agreement does not state, however, what is to constitute justification. That little question is left to future judgment.

Assuming the prior practice to be at least relevant, we may find ourselves in further trouble. I have spoken of the practice as an ascertained or readily ascertainable matter. But commonly it is only a question. Commonly there is widely conflicting evidence as to what was in fact done in the past. Ascertaining the facts with respect to an alleged practice is a difficult task not suggested by the assurance implicit in the word "practice." Nor is it a task which can fortunately be cast on the broad shoulders of a jury. But even after the facts are ascertained, what is their significance? When do they add up to a practice? And what practice?

Suppose that in the pipefitters' case, the employer says: "Sure we've used a rigger in the instances cited. But we did that because we had a rigger available with free time and used him to expedite the work. We still do that. But we never had any notion that we would supply a rigger in other circumstances or that the pipefitters can't be required to work without him." Or take the Christmas bonus. The employer says: "Of course we've paid the bonus. We did it in our discretion when we thought we could afford it and accomplish some good for our business. This year we are convinced that we cannot afford the bonus and, in any event, that it will do us no good." Or consider the union's reply to the company's claim that crib attendants always painted their cribs: "Sure they have. But that was their individual choice not a collective determination. The union is not out to stir up trouble. So long as nobody objected, we did not look into the question. But when a crib attendant did object, we then took our position. And we say that the attendant has the choice of accepting or rejecting the assignment." Such are the limitations commonly claimed for alleged practices, and their reality cannot be gainsaid merely because they were not recorded at the time or communicated to the other side. One cannot accompany his every

${ }^{11}$ Agreement Between Bethlehem Steel Co. and United Steelworkers, CIO, art. II, § 3 ( 1952$)$. 
act in the course of a busy day with explanations which would avoid prejudice for the future.

I have been discussing situations where the agreement is silent on important phases of the parties' dispute. But frequently the silence so assumed is a conclusion as to the very question in dispute. Generally one or the other of the parties urges strongly that while the agreement may not speak to the issue directly, it speaks to it indirectly but clearly.

A fairly common recurring dispute relates to the employment of independent outside contractors to do work which has been or can be done by the employer's own employees. For example, an employer may decide to engage an independent outside painting contractor to paint the plant, though he has painters in his own work force. Or he may decide to employ an outside contractor to make an electrical installation in the plant though he has his own electricians available for the work. The fact that some of his own employees may be on layoff while the outside contractor is working aggravates the situation, but is not necessarily controlling on the issue of interpretation involved. The employer's defense of his action in these cases normally runs along these lines: He contends that the determination whether to have particular work done by his own employees or by an outside contractor is part of his reserved "prerogative" which is either unrestrained by the agreement or recognized in the agreement by a provision of the kind mentioned above, leaving to him the "management of the business," the choice of "products to be manufactured," "the schedules of production," the "direction of the working forces," and the like. And he may add, with or without full disclosure of the supporting evidence, that he chose to engage an independent contractor for reasons of economy and business expediency.

The union's reliance is on the agreement. It points to the section, normally called recognition, which usually states that the employer recognizes the union as the collective bargaining agent for his employees in stated categories of work, such as production, or maintenance, or shop clerical and the like. This means, it argues, that work of the stated categories must be done by employees represented by the union. Its representation, it maintains, is not of any specified individuals as of any one time, but of the categories of work in the plant. Unless this meaning is accepted, the argument runs, the employer could drastically re- 
duce or destroy the bargaining unit for which the union was designated.

Of course, if this meaning is accepted, the considerations of economy and business expediency upon which the employer relies become irrelevant. But another possibility is suggested. The recognition clause, it is said, merely establishes the bargaining unit. But good faith, which must be an obligation in all agreements, requires that the employer refrain from deliberately impairing that unit without sufficient justification. In this view the recognition clause is violated only if the letting of the work to the outside contractor is without sufficient business justification.

But if this is the view found to be required by the agreement, then it launches an inquiry for which the agreement provides no guides at all: What is sufficient business justification? To what extent is the employer's own assertion of business judgment significant? How much or what kind of evidence is necessary to bolster his judgment? How much or how little economy is necessary to justify the assumed impairment of the bargaining unit?

Or take the example of employee discipline discussed above. The agreement may be quite clear that the employer has the power to discharge or discipline for cause. It may be quite clear in empowering the arbitrator to pass on grievances protesting the employer's action and even to reduce or modify penalties. But what and where are the guides for his decision? With the advent of grievance procedures and arbitration, discharge has ceased to be regarded as the only available disciplinary measure. Layoffs for various periods are now in general use; and suggestion is made of disciplinary demotions, transfers, reduction of seniority, and the like. What is proper cause for disciplinary action, and more particularly, for discharge rather than for some other penalty? May such measures as demotion or reduction in seniority be properly used for disciplinary purposes? How much weight is to be attached in each case to the employer's judgment, particularly in view of the fact that it is precisely that judgment which is sought to be curbed by the grievance procedure? What significance is to be attached to the personality of the individual employee, his age, his seniority, his prior record, his promise? What consideration, if any, is to be given to probable effects on plant "morale," the morale of supervisors as well as of the workers, and the effects at the time the decision is to be made as well as at the time the penalty is imposed? The frequent instances of stoppage of work in a 
department or a whole plant because of a disciplinary penalty imposed on a single employee indicates that what is involved is not merely the case of an individual but a group dispute. Factors of this kind should be and doubtless are considered by the parties in the other stages of the grievance procedure. Do they become irrelevant when the case is appealed to the arbitrator?

Here is, of course, the clearest illustration of the arbitrator's role as creative more than interpretive. It would be folly to suggest that all his work is of that character. Despite all platitudes as to the inherent ambiguity of language, there are cases in which the language of the agreement appears compelling and leaves no room for consideration of other evidence of meaning; cases in which the dispute seems frivolous or captious, or patently designed to shift the onus of decision from the party to the arbitrator, or a desperate effort to recapture a concession made in negotiations and subsequently regretted. Assuming, however, a real difference of opinion, what criteria may the arbitrator look to for the choice between conflicting interpretations, each of which is more or less permissible?

Answer in the form of rules or canons of interpretation is neither practical nor helpful. Long experience with statutory interpretation has failed to produce such answer. In the last analysis, what is sought is a wise judgment. It is judgment, said Holmes, that the world pays for. ${ }^{12}$ And we can only seek to be aware of the kind of care and preparation that is necessary in forming and pronouncing this judgment.

A proper conception of the arbitrator's function is basic. He is not a public tribunal imposed upon the parties by superior authority which the parties are obliged to accept. He has no general charter to administer justice for a community which transcends the parties. He is rather part of a system of self-government created by and confined to the parties. He serves their pleasure only, to administer the rule of law established by their collective agreement. They are entitled to demand that, at least on balance, his performance be satisfactory to them, and they can readily dispense with him if it is not.

To the extent that the parties are satisfied that the arbitrator is properly performing his part in their system of self-government, their voluntary cooperation in the achievement of the pur-

12 HoLMes, John Marshall, in SpeEcHes go (I934). 
poses of the collective agreement is promoted. When I speak of the satisfaction of the parties, I do not mean only the advocates who may present the case to the arbitrator, or the top echelons of management or union representatives. I mean rather all the persons whose cooperation is required - all the employees in the bargaining unit and all the representatives of management who deal with them, from the job foreman up.

Ideally, the arbitrator should be informed as fully as possible about the dispute which he is asked to resolve. He should hear all the contentions with respect to it which either party desires to make. For a party can hardly be satisfied that his case has been fully considered if he is not permitted to advance reasons which to him seem relevant and important.

The more serious danger is not that the arbitrator will hear too much irrelevancy, but rather that he will not hear enough of the relevant. Indeed, one advantage frequently reaped from wide latitude to the parties to talk about their case is that the apparent rambling frequently discloses very helpful information which would otherwise not be brought out. Rules of procedure which assure adequate opportunity to each party to prepare for and meet the other's contentions, or rules designed to encourage full consideration and effort at adjustment in the prior stages of the grievance procedure may be quite desirable. But they should not be such as to prevent full presentation of the controversy to the arbitrator before he is required to make final decision. For that would not only limit his resources for sound judgment, but would tend also to create dissatisfaction with the system.

The arbitrator may have to take a more active part in the investigation than does a trial court. This is not merely because, being charged with the responsibility for decision, he should be satisfied that he knows enough to be able to decide. A judge starts with some legal premises as to burden of proof or burden of going forward, which are presumably known to the lawyers who conduct the litigation and are binding on their clients. Even there these burdens are considerably eased by the modern practice of pretrial examination and discovery. But a collective agreement the arbitrator's law - rarely states any burden of proof; and the presentation to the arbitrator is not always in the hands of skilled advocates having the same training for the work and operating on common premises. A court's erroneous findings of fact in a particular litigation may work an injustice to the litigants but 
rarely disturb the future; similar error by an arbitrator may cause more harm by disturbing the parties' continuing relationship than by the injustice in the particular case.

Moreover, notions of burden of proof are hardly applicable to issues of interpretation. Even courts do not confine themselves to the parties' presentations in their search for the meaning of the law. Interpretation of the agreement requires, however, appreciation by the interpreter of relevant facts; and the arbitrator must assure himself as well as he can that he has them.

Finally, in this connection the arbitrator must be quite circumspect in explaining his decision on the ground of inadequate presentation, for his usefulness may depend in large part on the very people so designated for responsibility. And so, for several reasons, the arbitrator cannot simply sit back and judge a debate. He must seek to inform himself as fully as possible and encourage the parties to provide him with the information.

His choice from the more or less permissible interpretations of the language of the agreement, keeping the basic conceptions in mind, requires an appraisal of the consequences of each of the possibilities. Though all the parts of the agreement do not necessarily make a consistent pattern, the interpretation which is most compatible with the agreement as a whole is to be preferred over one which creates anomaly. The effects on efficiency, productivity, and cost are important factors to be considered. So are also the effects on the attitudes and interests of the employees. The two sets of factors are not always in opposition. An apparent increased cost may in some circumstances be more than repaid by the increased productivity resulting from the greater stimulus to voluntary cooperation. Practicality of the interpretation in its day-to-day applications is a related value. The interpretation, no matter how right in the abstract, is self-defeating and harmful to both sides if its day-to-day application provides further occasion for controversy and irritation.

Appraisal of probable consequences and practicality is no easy task and is not made on the basis of indisputable proof. The parties, too, make the appraisal. They differ with one another and they may differ with the arbitrator. But disagreement with the arbitrator by one or the other of the parties is normal and expectable and, of itself, not at all unhealthy. Indeed, the surprising thing is the extent of agreement that his award may meet within the ranks of both parties. For while a party may speak 
with one voice at the hearing, the fact is that there may be considerable difference of opinion among the many people who make up the artificial entity called the party.

The important question is not whether the parties agree with the award but rather whether they accept it, not resentfully, but cordially and willingly. Again, it is not to be expected that each decision will be accepted with the same degree of cordiality. But general acceptance and satisfaction is an attainable ideal. Its attainment depends upon the parties' seriousness of purpose to make their system of self-government work, and their confidence in the arbitrator. That confidence will ensue if the arbitrator's work inspires the feeling that he has integrity, independence, and courage so that he is not susceptible to pressure, blandishment, or threat of economic loss; that he is intelligent enough to comprehend the parties' contentions and empathetic enough to understand their significance to them; that he is not easily hoodwinked by bluff or histrionics; that he makes earnest effort to inform himself fully and does not go off half-cocked; and that his final judgment is the product of deliberation and reason so applied on the basis of the standards and the authority which they entrusted to him.

An important factor tending toward such general acceptance is the opinion accompanying the arbitrator's award. It has been urged by some that an arbitrator's award should be made without opinion or, explanation in order to avoid the dangers of accumulating precedents and subjecting arbitration to the rigidities of stare decisis in the law. Perhaps this view has merit when the particular arbitration is regarded as solely a means of resolving the particular stalemate and nothing else. It is an erroneous view for the arbitration which is an integral part of the system of selfgovernment and rule of law that the parties establish for their continuing relationship.

In this system opinions are necessary, first, to assure the parties that the awards are based on reason applied to the agreement in the manner I have described. ${ }^{13}$ To be sure, the opinions may convince the parties that their arbitrator is inadequate and should be replaced. This may work a hardship, and at times even an injustice, on the arbitrator. But that is a risk which the parties are

\footnotetext{
${ }^{13}$ I pass over the desirability of an opinion to assure the arbitrator himself that he has reached his conclusion in that way.
} 
entitled to impose on his occupation and which is a necessary feature of the system.

Secondly, in this system a form of precedent and stare decisis is inevitable and desirable. I am not referring to the use in one enterprise, say United States Steel, of awards made by another arbitrator in another enterprise, say General Motors. Because the publishing business has made arbitration awards generally available, they are being used in this way both by the parties and by arbitrators. But they are not so used in the belief that they are entitled to any particular precedential value, for they are not so entitled. Their value, if any, lies rather in their suggestion of approach or line of argument, or perhaps in their character of evidence as to practice in other enterprises. As such evidence, it must be used, of course, with great circumspection because of its limited character, and with ample opportunity for the parties to consider it.

But the precedent of which I am now speaking refers to the successive decisions within the same enterprise. Even in the absence of arbitration, the parties themselves seek to establish a form of stare decisis or precedent for their own guidance - by statements of policy, instructions, manuals of procedure, and the like. This is but a means of avoiding the pain of rethinking every recurring case from scratch, of securing uniformity of action among the many people of co-ordinate authority upon whom each of the parties must rely, of assuring adherence in their action to the policies established by their superiors, and of reducing or containing the possibilities of arbitrary or personal discretion.

When the parties submit to arbitration in the system of which I speak, they seek not merely resolution of the particular stalemate, but guidance for the future, at least for similar cases. They could hardly have a high opinion of the arbitrator's mind if it were a constantly changing mind. Adherence to prior decisions, except when departure is adequately explained, is one sign that the determinations are based on reason and are not merely random judgments.

The arbitrator's opinion can help in rationalizing the agreement and the parties' contentions with respect to it and in fostering greater appreciation by them of each other's views and needs with respect to the problem at hand. Its greatest utility lies in its effect, not merely on the advocates who presented the case or the higher authorities in the enterprise, but on what might be 
called the rank and file - the workers in the shop and their supervisors. It is the rank and file that must be convinced. For the temptation to resort to job action is ever present and is easily erupted. The less their private rule of law is understood by the workers and the more remote from their participation are the decisions made on their grievances, the greater is the likelihood of wildcat stoppages or other restraints on productivity. The likelihood can be decreased by bringing the arbitration close to the shop, not only in the hearings and investigations, but also in the opinion which explains the award.

The awards must necessarily set precedents for recurring cases and the opinions must necessarily provide guidance for the future in relating decision to reason and to more or less mutually accepted principle. Consistency is not a lawyers' creation. It is a normal urge and a normal expectation. It is part of the ideal of equality of treatment. The lawyer's contribution, indeed, is his differentiation of rational, civilized consistency from apparent consistency. Let me give you an example. In many appeals from disciplinary penalties imposed by the employer, I heard the union argue earnestly that the penalty should be reduced because of the employee's long service record. I was persuaded and held that the employee's seniority should be considered in fixing the size of his penalty. Then came a case in which two employees committed the same offense at the same time, and one was given a larger penalty than the other. The union protested the larger penalty as being an obvious impairment of the principle of equality. This was not necessarily conscious opportunism, although there is always a good deal of that. A period of education was required to effect the realization, not only by the advocates, but by the rank and file that the equality for which they themselves contended in the area of discipline necessitated different penalties for the same offense whenever factors other than the offense itself were considered.

The arbitrator's opinions may thus be a valuable means of seating reason in labor relations. But the opinions must be carefully restrained. I venture to think that the greater danger to be guarded against is that too much will be said rather than too little. If the opinion wanders too far from the specific problem, in order to rationalize and guide, it runs great risk of error and subsequent embarrassment to the arbitrator himself. Even more unfortunately, it may lead the parties to distrust him because he 
has gone beyond the necessities of the case and has assumed to regulate their affairs in excess of their consent.

The danger of deciding too much or too early appears in another way. The parties themselves, each confidently expecting a decision its way, may press the arbitrator to decide issues which might better be left undecided or at least delayed until time and experience provide greater assurance of wise judgment. To the dogmatic and the partisan, there is no need for delay; their minds are made up and, to them, delay is confusing and exasperating. The United States Supreme Court has seen the dangers of premature decision and has developed standards for avoiding it, such as the insistence upon a "case or controversy" and the refusal to pass upon a constitutional question when a narrower ground will suffice for the case in hand. The conscientious arbitrator sometimes yearns for similar means of avoiding or delaying decision on issues which he feels unready to decide. For it must be remembered that the arbitrator's decision has a strength and a carry-over which does not exist in the case of an adjustment made by the parties in the lower stages of the grievance procedure.

Consider this example: The agreement sets forth certain classifications with attached rates of pay - ironworker, millwright, crib builder, sashman, belt repairman, and the like. The work of all these classifications is related by features common to all of them. In some plants all the work might be covered by perhaps one or two classifications rather than by a half-dozen. The agreement contains no job descriptions outlining the work of each classification, or if there are job descriptions they are either unilaterally adopted, or sketchy and expressly not exhaustive, or both. Disputes arise as to whether particular assignments made on certain days by supervision fall properly within one or another of the classifications. The particular cases may come to the arbitrator on appeal of disciplinary penalties imposed on employees who refused the assignments on the ground that they were not within the classifications of these employees; or they may come on the grievances of employees claiming that they were deprived of work belonging to their classification when the work was assigned to others. Such cases are vexing indeed, for the parties as well as the arbitrator. Even after long experience, he may find it practically impossible to draw clear and fine lines of demarcation between the several classifications. If he attempts to prick 
points in a future line by deciding the individual cases as they arise, his task is not much easier because he lacks confidence as to the direction in which he is going and knows that each case may be a prelude to many others. To decide that the issues are beyond his jurisdiction, because the agreement does not demarcate the classifications, is unsatisfactory because that may in effect be a decision for one of the parties and because the fact is that the dispute relates to a provision of the agreement.

In cases of this character, and others in which the arbitrator conscientiously feels baffled, it may be much wiser to permit him to mediate between the parties for an acceptable solution. I do not suggest it for all cases; nor do I urge that settlement is always better than decision. I suggest it only for those cases where decision with confidence seems impossible and where the arbitrator is quite at sea with respect to the consequences of his decision in the operation of the enterprise. In such cases, an adjustment worked out by him with the parties is the most promising course. And the possibility of adjustment is enhanced if he is able to exert the gentle pressure of a threat of decision. In this activity, as in the case of the arbitrator's socializing or meeting with the parties separately, the dangers envisaged with respect to judges or other governmental personnel are not equally applicable. For the parties' control of the process and their individual power to continue or terminate the services of the arbitrator are adequate safeguards against these dangers.

The example I cited comes from my own experience. With the parties' indulgence, though not with their prior consent, I withheld decision and let numerous cases accumulate, meanwhile gaining more illustrations of the scope of the problem and encouraging the parties to search for solution. We finally came up with a mutual understanding which amalgamated the several classifications into one with an appropriate adjustment of rate, reclassified the affected employees, disposed of the accumulated cases, and eliminated the problem for the future. To avoid certain internal difficulties the understanding was recorded not as a signed agreement, but rather as a decision of the umpire, the parties having waived for this case the normal limitations on his jurisdiction.

I have attempted in this paper to sketch the autonomous rule of law and reason which the collective labor agreement establishes. It has, of course, its limitations and its faults. It relies upon 
wholehearted acceptance by the parties and requires a congenial and adequate arbitrator, as I have explained, who is neither timid nor rash and who feels a responsibility for the success of the system. The arbitration may be resented by either party as an impairment of its authority or power. It is susceptible of use for buck-passing and face-saving. And it may sometimes encourage litigiousness. But when the system works fairly well, its value is great. To consider its feature of arbitration as a substitute for court litigation or as the consideration for a no-strike pledge is to take a foreshortened view of it. In a sense it is a substitute for both - but in the sense in which a transport airplane is a substitute for a stagecoach. The arbitration is an integral part of the system of self-government. And the system is designed to aid management in its quest for efficiency, to assist union leadership in its participation in the enterprise, and to secure justice for the employees. It is a means of making collective bargaining work and thus preserving private enterprise in a free government. When it works fairly well, it does not need the sanction of the law of contracts or the law of arbitration. It is only when the system breaks down completely that the courts' aid in these respects is invoked. But the courts cannot, by occasional sporadic decision, restore the parties' continuing relationship; and their intervention in such cases may seriously affect the going systems of selfgovernment. When their autonomous system breaks down, might not the parties better be left to the usual methods for adjustment of labor disputes rather than to court actions on the contract or on the arbitration award? I suggest that the law stay out - but, mind you, not the lawyers. 